Provided for non-commercial research and education use. Not for reproduction, distribution or commercial use.

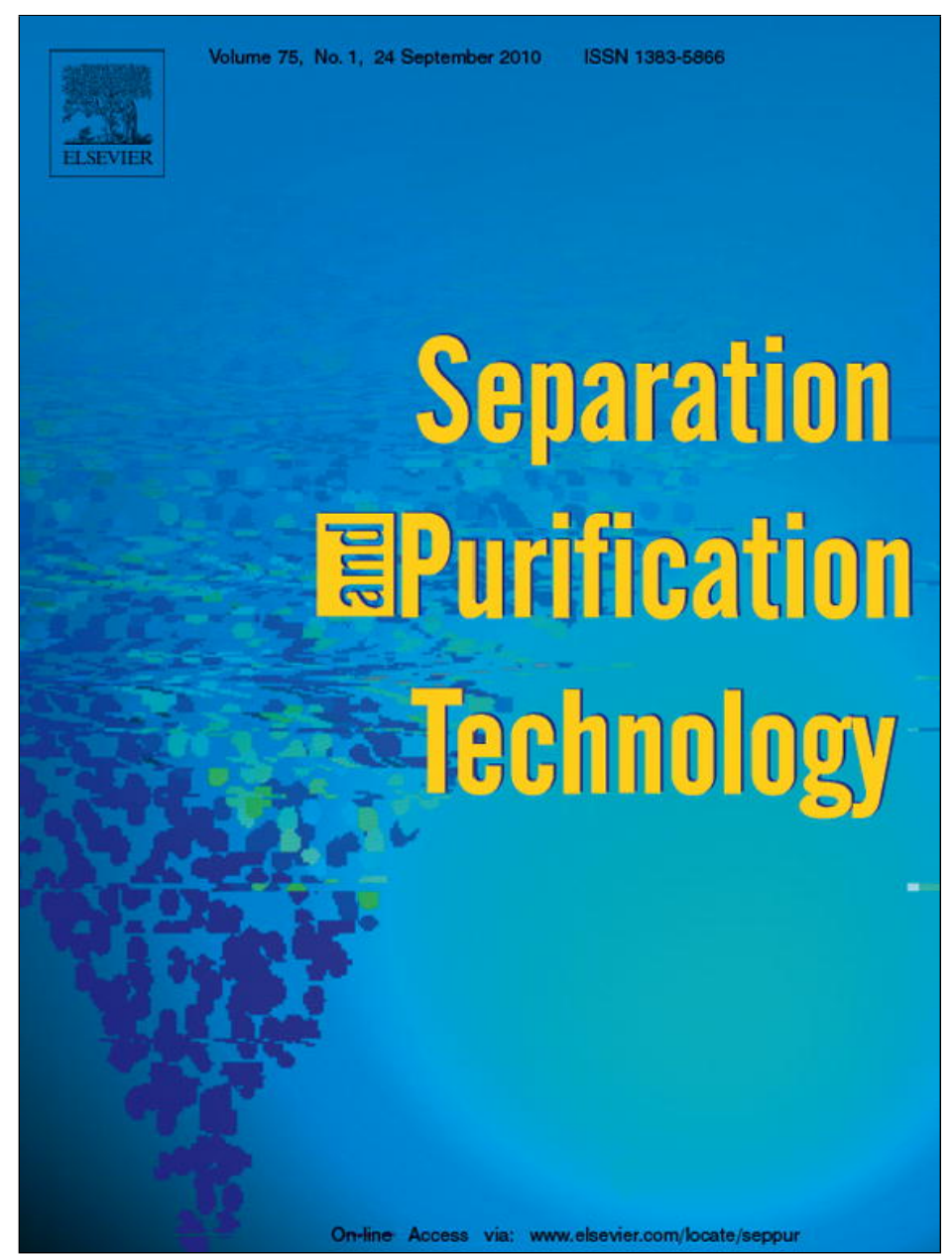

This article appeared in a journal published by Elsevier. The attached copy is furnished to the author for internal non-commercial research and education use, including for instruction at the authors institution and sharing with colleagues.

Other uses, including reproduction and distribution, or selling or licensing copies, or posting to personal, institutional or third party websites are prohibited.

In most cases authors are permitted to post their version of the article (e.g. in Word or Tex form) to their personal website or institutional repository. Authors requiring further information regarding Elsevier's archiving and manuscript policies are encouraged to visit:

http://www.elsevier.com/copyright 


\title{
Extraction of vanillin using ionic-liquid-based aqueous two-phase systems
}

\author{
Ana Filipa M. Cláudio, Mara G. Freire, Carmen S.R. Freire, Armando J.D. Silvestre, João A.P. Coutinho* \\ Departamento de Química, CICECO, Universidade de Aveiro, Campus Universitário de Santiago, 3810-193 Aveiro, Portugal
}

\section{A R T I C L E I N F O}

\section{Article history:}

Received 7 May 2010

Received in revised form 12 July 2010

Accepted 13 July 2010

\section{Keywords:}

Aqueous two phase systems

Vanillin

Ionic liquids

Extraction

\begin{abstract}
A B S T R A C T
To explore proper extractive solvents and to design an optimized separation process it is highly imperative to understand the molecular-based phenomena governing the solutes partitioning. Moreover, the development of new techniques for the biomolecules separation and purification, while maintaining their functional characteristics unchanged, is still ongoing. Therefore, in this work, the partition coefficients of vanillin, a compound with well-known organoleptic properties, were determined using improved ionicliquid-based aqueous two-phase systems (ATPS). Three main parameters were evaluated through the vanillin partitioning process: the ionic liquid (IL) cation and anion structure, the temperature of equilibrium and the available concentration of vanillin in the global system. In all systems and conditions tested, vanillin preferentially migrates for the IL-rich phase. In addition, the three studied parameters largely influence the vanillin partitioning. In an attempt to elucidate the thermodynamics of the partitioning process, the standard molar thermodynamic functions of transfer of vanillin were also determined based on the temperature dependence data. These data indicate that the partition of vanillin results from an interplay between enthalpic and entropic contributions where both the IL anion and more complex cations play an essential role. Moreover, viscosities and densities of both aqueous phases were experimentally measured at the mass fraction compositions for which the partition coefficients were determined. The results gathered in this work indicate that IL-based ATPS can be further employed in the extraction and purification of vanillin from different matrices, as confirmed by the large partition coefficients obtained and improved low viscosity systems.
\end{abstract}

(c) 2010 Elsevier B.V. All rights reserved.

\section{Introduction}

The interest on vanillin relays on the product diverse applications. Vanillin, 3-methoxy-4-hydroxybenzaldehyde (Fig. 1), is a biomolecule used for several purposes, whose recovery and purification by cost-effective and environmentally safe processes is still a major concern. Vanillin is one of the mostly appreciated fragrant substances aiming at creating artificial flavors in a wide range of commercial products. Vanillin or vanilla are currently used in food, beverages, and pharmaceutical products to provide satisfying flavors, as well as in the cosmetic industry for its fragrance [1]. Beyond these flavor and fragrance applications, vanillin is also used as a chemical intermediate in the production of pharmaceuticals and fine chemicals, such as biocides, due to its phenolic character $[2,3]$.

In industry, liquid-liquid extraction processes are often important techniques used for the purification of biomolecules due to their large versatility, ranging from an higher effectiveness, higher yield, improved purity degree, proper selectivity, technological simplicity and lower cost, to a good combination between

\footnotetext{
* Corresponding author. Tel.: +351 234 370200; fax: +351234 370084.

E-mail address: jcoutinho@ua.pt (J.A.P. Coutinho).
}

the recovery and purification steps [4-6]. The extraction of biomolecules is typically carried out using volatile organic solvents because of their immiscibility with aqueous media [7]. The most common organic solvents used present, nevertheless, some disadvantages, such as high volatility and toxicity, and the possibility of denaturating enzymes and proteins to be recovered [5]. Aiming at avoiding the use of organic solvents as the extractive phase one of the potential methods relays on the application of aqueous two-phase systems (ATPS). Separation of biological molecules and particles using ATPS dates to 1958 and were introduced by Albertsson [8]. ATPS consist in two aqueous-rich phases containing typical polymer/polymer, polymer/salt or salt/salt combinations.

To improve the extraction efficiencies and to minimize environmental impacts the replacement of ordinary organic solvents by ionic liquids (ILs) has been a promising alternative. Organic solvents may be substituted by hydrophobic ILs as a second immiscible liquid phase with aqueous media [9] or by the use of ATPS incorporating hydrophilic ILs [6,10-13]. Indeed, few years ago, Gutowski et al. [12] showed that aqueous solutions of imidazolium-based ILs can form ATPS under the addition of appropriate inorganic salts, such as $\mathrm{K}_{3} \mathrm{PO}_{4}$. Since then, the equilibrium properties of systems comprising ILs, for the development of specific extraction and isolation procedures, have been inves- 


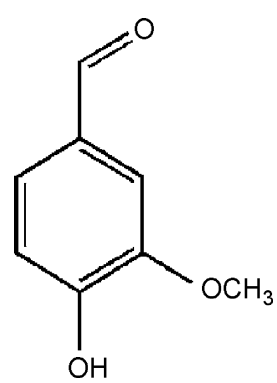

Fig. 1. Chemical structure of vanillin.

tigated at our laboratory [9,13-19]. It was already shown that ATPS formed by $\mathrm{K}_{3} \mathrm{PO}_{4}$ and ILs are extremely advantageous for the partition of several biomolecules yielding larger partition coefficients than those conventionally obtained with polymer-inorganic salts or polymer-polymer ATPS $[6,10,13]$. The extractive potential of biomolecules using IL-based ATPS was previously studied for distinct compounds, such as testosterone and epitestosterone, alkaloids, antibiotics, bovine serum albumin, penicillin G, Ltryptophan and food coulorants [6,10,13,20-24].

The initial interest on ILs as alternative extractive fluids results from their physical and chemical advantages, namely negligible flammability and vapour pressure, high solvation ability, high chemical stability, high selectivity, and easiness in recovering and recycling them [25-29]. Moreover, it was already shown that adequate ILs do not significantly inactivate enzymes ensuring thus their structural integrity and enzymatic activity $[5,27]$. In addition, once the ILs physicochemical properties are strongly dependent on the IL nature, the possibility of changing their properties through the manipulation of the ions that compose them represents an important advantage. Their "tunnability" makes of ILs unique compounds that can be designed with precise conditions for a particular process, as well as to manipulate their extraction capabilities for specific biomolecules $[6,28,30]$.

Attempting at develop the understanding on the molecular mechanisms behind the partition of biomolecules in ATPS containing ILs, and to identify the best ILs for the extraction of phenolic compounds, in this work an extensive study was conducted using vanillin, a phenolic aldehyde, as the partitioning molecule. For that purpose, several extraction parameters were studied in ternary systems composed by imidazolium-based ILs, water and $\mathrm{K}_{3} \mathrm{PO}_{4}$, namely the influence of the IL cation and anion, the temperature of extraction and the concentration of vanillin. Moreover, viscosities and densities of both the inorganic salt-rich phase and the IL-rich phase were measured in the temperature range from $298.15 \mathrm{~K}$ to $318.15 \mathrm{~K}$ to evaluate the advantage of using IL-based ATPS.

\section{Experimental}

\subsection{Materials}

Since it is highly difficult to attain measurements through all the possible combinations between cations and anions in ILs, it is thus crucial to perform measurements on selective systems, aiming at providing results that can be further used as optimized extractions procedures. Therefore, this work evaluated the extraction ability of several IL-based ATPS for vanillin. All ILs studied are based on the imidazolium cation: 1-ethyl-3-methylimid azolium chloride, $\left[\mathrm{C}_{2} \mathrm{mim}\right] \mathrm{Cl}$; 1-butyl-3-methylimidazolium chloride, $\left[\mathrm{C}_{4} \mathrm{mim}\right] \mathrm{Cl}$; 1-hexyl-3-methylimidazolium chloride, $\quad\left[\mathrm{C}_{6} \mathrm{mim}\right] \mathrm{Cl}$; 1-heptyl-3-methylimidazolium chloride, $\left[\mathrm{C}_{7} \mathrm{mim}\right] \mathrm{Cl}$; 1-decyl-3-methylimidazolium chloride, $\left[\mathrm{C}_{10} \mathrm{mim}\right] \mathrm{Cl}$; 1-allyl-3-methylimidazolium chloride, [amim]Cl; 1-benzyl- 3-methylimidazolium chloride, $\quad\left[\mathrm{C}_{7} \mathrm{H}_{7} \mathrm{mim}\right] \mathrm{Cl} ; \quad$ 1-hydro xyethyl-3-methylimidazolium chloride, $\left[\mathrm{OHC}_{2} \mathrm{mim}\right] \mathrm{Cl}$; 1-butyl-3-methylimidazolium bromide, [ $\left.\mathrm{C}_{4} \mathrm{mim}\right] \mathrm{Br}$; 1-butyl3-methylimidazolium methanesulfonate, $\left[\mathrm{C}_{4} \mathrm{mim}\right]\left[\mathrm{CH}_{3} \mathrm{SO}_{3}\right]$; 1-butyl-3-methylimidazolium acetate, $\left[\mathrm{C}_{4} \mathrm{mim}\right]\left[\mathrm{CH}_{3} \mathrm{CO}_{2}\right] ; 1$ butyl-3-methylimidazolium methylsulfate $\left[\mathrm{C}_{4} \mathrm{mim}\right]\left[\mathrm{CH}_{3} \mathrm{SO}_{4}\right]$; 1-butyl-3-methyl-imidazoliumtriflu oromethanesulfonate, $\left[\mathrm{C}_{4} \mathrm{mim}\right]\left[\mathrm{CF}_{3} \mathrm{SO}_{3}\right]$; 1-butyl-3-methylimidazolium dicyanamide, $\left[\mathrm{C}_{4} \mathrm{mim}\right]\left[\mathrm{N}(\mathrm{CN})_{2}\right]$. The ILs were supplied by Iolitec. To reduce the water and volatile compounds content to negligible values, ILs individual samples were dried under constant agitation at vacuum and moderate temperature ( $333 \mathrm{~K}$ ) for a minimum of $48 \mathrm{~h}$. After this procedure, the purity of each IL was further checked by ${ }^{1} \mathrm{H},{ }^{13} \mathrm{C}$ and ${ }^{19} \mathrm{~F}$ NMR spectra and found to be $>99 \mathrm{wt} \%$ for all samples. The inorganic salt $\mathrm{K}_{3} \mathrm{PO}_{4}$ was supplied from Sigma with a purity level $>98 \mathrm{wt} \%$. Vanillin, >99 wt\% pure, was supplied from Aldrich. The molecular structures of vanillin and the studied ILs are depicted in Figs. 1 and 2, respectively. The water employed was double distilled, passed across a reverse osmosis system and further treated with a Milli-Q plus 185 water purification apparatus.

\subsection{Vanillin partitioning}

A ternary mixture was prepared within the biphasic region containing $15 \mathrm{wt} \%$ of $\mathrm{K}_{3} \mathrm{PO}_{4}, 60 \mathrm{wt} \%$ of an aqueous solution of vanillin and $25 \mathrm{wt} \%$ of all above mentioned ILs. Only for $\left[\mathrm{OHC}_{2} \mathrm{mim}\right] \mathrm{Cl}$ a different composition ( $15 \mathrm{wt} \%$ of $\mathrm{K}_{3} \mathrm{PO}_{4}, 40 \mathrm{wt} \%$ of IL and $45 \mathrm{wt} \%$ of the aqueous solution of vanillin) was used due to the smaller two-phase region obtained within this IL. The ternary mixtures compositions were chosen based on the phase diagrams of each IL reported in previous works $[6,10]$. The ternary compositions were prepared by weight with an uncertainty of $\pm 10^{-5} \mathrm{~g}$. The vanillin content influence was studied using different concentrations of the compound at the aqueous phase composition $\left(0.5 \mathrm{~g} \mathrm{dm}^{-3}, 1.0 \mathrm{~g} \mathrm{dm}^{-3}\right.$, $2.5 \mathrm{~g} \mathrm{dm}^{-3}, 5.0 \mathrm{~g} \mathrm{dm}^{-3}$ and $7.5 \mathrm{~g} \mathrm{dm}^{-3}$ which correspond to $3.3 \times 10^{-3} \mathrm{~mol} \mathrm{dm}^{-3}, 6.6 \times 10^{-3} \mathrm{~mol} \mathrm{dm}^{-3}, 1.6 \times 10^{-2} \mathrm{~mol} \mathrm{dm}^{-3}$, $3.3 \times 10^{-2} \mathrm{~mol} \mathrm{dm}^{-3}$ and $4.9 \times 10^{-2} \mathrm{~mol} \mathrm{dm}^{-3}$, respectively).

Each mixture (IL, $\mathrm{K}_{3} \mathrm{PO}_{4}$ and aqueous solution of vanillin) was vigorously stirred and allowed to reach equilibrium by the separation of both phases for $12 \mathrm{~h}$ and at the temperature of interest using small ampoules $\left(10 \mathrm{~cm}^{3}\right)$ especially built for such extraction steps. A preliminary study showed that the equilibration of vanillin was attained after a period of $12 \mathrm{~h}$. The time required to establish the equilibrium of vanillin was experimentally determined by measuring the concentration of vanillin in each phase at different times until reproducible data were obtained. The temperatures evaluated were $288.15 \mathrm{~K}, 298.15 \mathrm{~K}, 308.15 \mathrm{~K}, 318.15 \mathrm{~K}$ and $328.15 \mathrm{~K}$ within an uncertainty of $\pm 0.01 \mathrm{~K}$, and attained using an air bath equipped with a Pt 100 probe and PID controller or making use of a refrigerated water bath, Julabo F34. After a careful separation of both phases, the amount of vanillin at each aqueous phase was quantified through UV-spectroscopy, using a SHIMADZU UV-1700, Pharma-Spec Spectrometer, at wavelength of $280 \mathrm{~nm}$. Calibration curves were properly established. At least three individual samples of each phase were quantified in order to determine the vanillin partition coefficients and the respective standard deviations. Possible interferences of both $\mathrm{K}_{3} \mathrm{PO}_{4}$ and all ILs with the analytical method were investigated and found to be not significant at the working conditions used.

The partition coefficients of vanillin, $K_{\mathrm{Van}}$, were determined as the ratio of the concentration of vanillin in the IL and in the inorganic salt $\left(\mathrm{K}_{3} \mathrm{PO}_{4}\right)$ aqueous-rich phases, accordingly to:

$$
K_{\mathrm{Van}}=\frac{[\mathrm{Van}]_{\mathrm{IL}}}{[\operatorname{Van}]_{\mathrm{K}_{3} \mathrm{PO}_{4}}}
$$




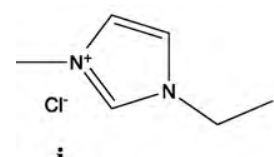

i<smiles></smiles>

ii

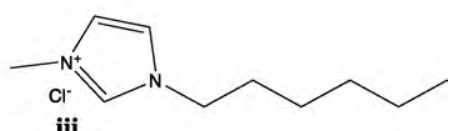<smiles>CCCCCCCn1cc[n+](C)c1</smiles><smiles>CCCCCCCCCCn1cc[n+](C)c1</smiles><smiles>C=CCn1cc[n+](C)c1</smiles>

vi<smiles></smiles>

ix

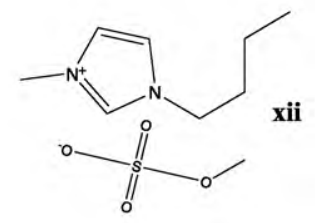<smiles>C[n+]1ccn(Cc2ccccc2)c1</smiles>

vii<smiles>CCCCn1cc[n+](C)c1</smiles>

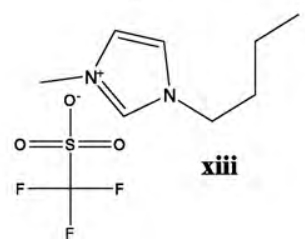

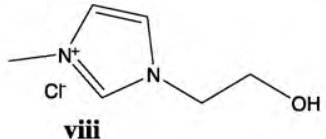<smiles></smiles>

$\mathbf{x i}$

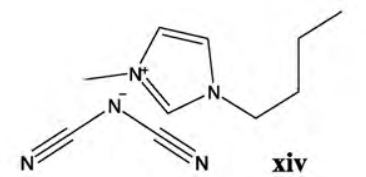

Fig. 2. Chemical structure of the studied ILs: (i) $\left[\mathrm{C}_{2} \mathrm{mim}\right] \mathrm{Cl}$; (ii) $\left[\mathrm{C}_{4} \mathrm{mim}\right] \mathrm{Cl}$; (iii) $\left[\mathrm{C}_{6} \mathrm{mim}\right] \mathrm{Cl}$; (iv) $\left[\mathrm{C}_{7} \mathrm{mim}\right] \mathrm{Cl}$; (v) $\left[\mathrm{C}_{10} \mathrm{mim}\right] \mathrm{Cl}$; (vi) $[\mathrm{amim}] \mathrm{Cl}$; (vii) $\left[\mathrm{C}_{7} \mathrm{H}_{7} \mathrm{mim}\right] \mathrm{Cl}$; (viii) $\left[\mathrm{OHC}_{2} \mathrm{mim}\right] \mathrm{Cl}$; (ix) $\left[\mathrm{C}_{4} \mathrm{mim}\right] \mathrm{Br} ;(\mathrm{x})\left[\mathrm{C}_{4} \mathrm{mim}\right]\left[\mathrm{CH}_{3} \mathrm{SO}_{3}\right] ;(\mathrm{xi})\left[\mathrm{C}_{4} \mathrm{mim}\right]\left[\mathrm{CH}_{3} \mathrm{CO}_{2}\right] ;(\mathrm{xii})\left[\mathrm{C}_{4} \mathrm{mim}\right]\left[\mathrm{CH}_{3} \mathrm{SO}_{4}\right] ;(\mathrm{xiii})\left[\mathrm{C}_{4} \mathrm{mim}\right]\left[\mathrm{CF}_{3} \mathrm{SO}\right] ;$ (xiv) $\left[\mathrm{C}_{4} \mathrm{mim}\right]\left[\mathrm{N}\left(\mathrm{CN}_{2}\right]\right.$;

where [Van $]_{\mathrm{IL}}$ and $[\mathrm{Van}]_{\mathrm{K}_{3} \mathrm{PO}_{4}}$ are the concentration of vanillin in the IL and in the inorganic salt aqueous-rich phases, respectively. For all the ternary mixtures evaluated, and at the compositions used, the top layer is the IL-rich phase while the bottom phase is the $\mathrm{K}_{3} \mathrm{PO}_{4}$-rich phase.

\subsection{Density and viscosity}

Density and viscosity of the phases formed during the vanillin extraction were measured using an automated SVM 3000 Anton Paar rotational Stabinger viscometer-densimeter in the temperature range from $298.15 \mathrm{~K}$ to $318.15 \mathrm{~K}$, within an uncertainty of $\pm 0.02 \mathrm{~K}$. The dynamic viscosity has a relative uncertainty within $0.35 \%$, while the absolute uncertainty in density is $\pm 5 \times 10^{-4} \mathrm{~g} \mathrm{~cm}^{-3}$.

\section{Results and discussion}

The extraction of a molecule with ATPS strongly depends on the ability to manipulate the physical/chemical properties of the phases aiming at obtaining high partition coefficients and specific selectivity for the biomolecules of interest. Several advances can be used to control the molecules partitioning, such as the chemical nature of the system, temperature of equilibrium, system composition and inclusion of antisolvents, co-solvents or amphiphilic structures. Three process variables were evaluated in this work: the IL cation and anion structure, the temperature of extraction, and the initial concentration of vanillin. To optimize the ILs to be used and operating conditions for the vanillin extraction, it is of high importance to understand the physicochemical issues that rule the biomolecule partitioning between the two equilibrated aqueous-rich phases. The values of the partition coefficients between the two phases result from a complex balance between IL-vanillin, $\mathrm{K}_{3} \mathrm{PO}_{4}$-vanillin and water-vanillin interactions and are determined by the relative strengths of the interactions of the biomolecule with each of the components present in the sys- tem. Taking into account the vanillin and ILs molecular structures depicted in Figs. 1 and 2, these interactions may result from dispersive forces, electrostatic interactions, hydrogen-bonding, steric and conformational effects, molecular size and $\pi \cdots \pi$ stacking $[6,31,32]$. The partitioning of vanillin into one phase requires the disruption of interactions between its components to create a cavity where the solute can be accommodated. It is thus expected that vanillin will partition to a phase where less energy is required to create a cavity and that the new interaction formed between vanillin and its solvation neighbors are indeed more favorable. For all the studied systems it was observed that vanillin preferentially migrates for the IL-rich phase $\left(K_{\mathrm{Van}}>1\right)$ resulting from the favorable interactions between vanillin and imidazolium-based ILs, and from the lower energy required to create a cavity in the IL-rich phase due to the lower surface tension of this phase [33]. The mass fraction compositions used for the determination of each partition coefficient, as well as the partition coefficients values and respective standard deviations, are presented in Supporting Information.

\subsection{Effect of IL ions in vanillin partitioning}

In order to evaluate the IL ions influence in the extraction of vanillin several combinations were performed. For the cation improvement study, the chloride anion was kept, while combined with the following cations: $\left[\mathrm{C}_{2} \mathrm{mim}\right]^{+},\left[\mathrm{C}_{4} \mathrm{mim}\right]^{+},\left[\mathrm{C}_{6} \mathrm{mim}\right]^{+}$, $\left[\mathrm{C}_{7} \mathrm{mim}\right]^{+},\left[\mathrm{C}_{10} \mathrm{mim}\right]^{+},[\mathrm{amim}]^{+},\left[\mathrm{OHC}_{2} \mathrm{mim}\right]^{+}$and $\left[\mathrm{C}_{7} \mathrm{H}_{7} \mathrm{mim}\right]^{+}$. The selected ILs allow the study of the alkyl side chain length effect, as well as the study of additional functional groups. The IL anion was evaluated through the use of the $\left[\mathrm{C}_{4} \mathrm{mim}\right]^{+}$cation combined with the following anions: $\mathrm{Cl}^{-}, \mathrm{Br}^{-},\left[\mathrm{CH}_{3} \mathrm{CO}_{2}\right]^{-},\left[\mathrm{CH}_{3} \mathrm{SO}_{3}\right]^{-},\left[\mathrm{CF}_{3} \mathrm{SO}_{3}\right]^{-}$, $\left[\mathrm{CH}_{3} \mathrm{SO}_{4}\right]^{-}$and $\left[\mathrm{N}(\mathrm{CN})_{2}\right]^{-}$. All of these studies were performed at $298.15 \mathrm{~K}$.

The partition coefficients measured at $298.15 \mathrm{~K}$ are presented in Figs. 3 and 4 and show that $K_{\text {Van }}$ ranges between 2.72 and 49.59 (at approximately the same mass fraction com- 


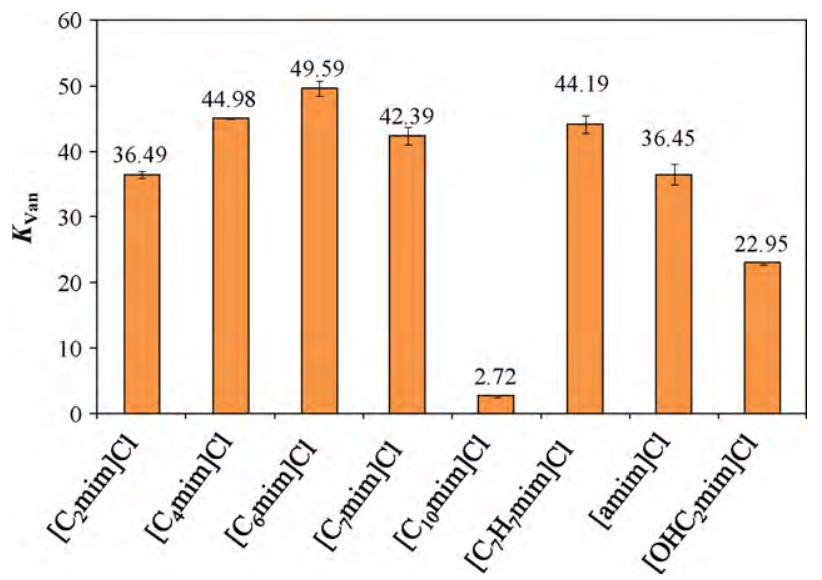

Fig. 3. Partition coefficients of vanillin in chloride-based ILs $+\mathrm{K}_{3} \mathrm{PO}_{4}$ ATPS at $298.15 \mathrm{~K}$.

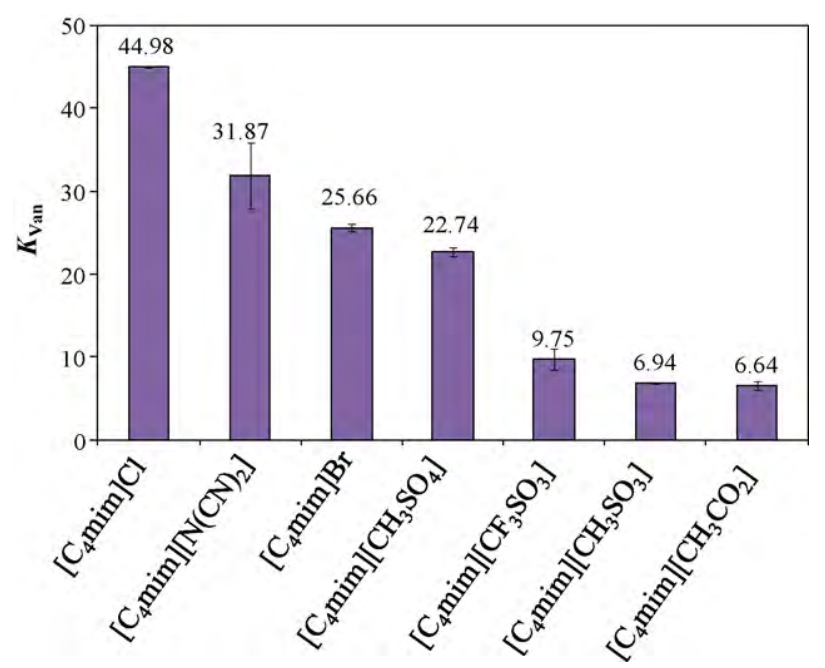

Fig. 4. Partition coefficients of vanillin in $\left[\mathrm{C}_{4}\right.$ mim]-based $I L s+K_{3} \mathrm{PO}_{4}$ ATPS at $298.15 \mathrm{~K}$

positions of IL and inorganic salt). Regarding the IL cation influence, the ability of ILs to extract vanillin follows the order: $\left[\mathrm{C}_{6} \mathrm{mim}\right] \mathrm{Cl}>\left[\mathrm{C}_{4} \mathrm{mim}\right] \mathrm{Cl}>\left[\mathrm{C}_{7} \mathrm{H}_{7} \mathrm{mim}\right] \mathrm{Cl}>\left[\mathrm{C}_{7} \mathrm{mim}\right] \mathrm{Cl}>\left[\mathrm{C}_{2} \mathrm{mim}\right] \mathrm{Cl}$

$\approx[\mathrm{amim}] \mathrm{Cl}>\left[\mathrm{OHC}_{2} \mathrm{mim}\right] \mathrm{Cl} \gg\left[\mathrm{C}_{10} \mathrm{mim}\right] \mathrm{Cl}$. Increasing the alkyl side chain of the imidazolium cation there is an increase on the vanillin partition coefficients, reaching a maximum with $\left[\mathrm{C}_{6} \mathrm{mim}\right] \mathrm{Cl}$, followed by a decrease until $\left[\mathrm{C}_{10} \mathrm{mim}\right] \mathrm{Cl}$. Indeed, the lowest partition coefficient of vanillin was observed for the IL with the longest cation alkyl chain length, $\left[\mathrm{C}_{10} \mathrm{mim}\right] \mathrm{Cl}$. Increasing the size of the alkyl side chain it increases the IL free volume while decreasing the surface tension of the system [33], and thus decreasing the energy of cavity formation to accommodate a vanillin molecule. However, the increase of the alkyl side chain length leads to a decrease on the strength of the coulombic and polar interactions, while increasing the dispersive interactions, between the IL ions [15,34]. Therefore, these two contributions will act in different directions leading to the observed maximum value on the partition coefficients at about $\left[\mathrm{C}_{6} \mathrm{mim}\right] \mathrm{Cl}$.

The presence of a double bound, an aromatic moiety or an hydroxyl group at the imidazolium alkyl chain increases the IL hydrophilicity or the IL affinity for water [10]. Nevertheless, the partition coefficients of vanillin were not significantly enhanced using $\left[\mathrm{C}_{7} \mathrm{H}_{7} \mathrm{mim}\right] \mathrm{Cl}$, [amim] $\mathrm{Cl}$ or $\left[\mathrm{OHC}_{2} \mathrm{mim}\right] \mathrm{Cl}$ when compared with the values obtained for $\left[\mathrm{C}_{7} \mathrm{mim}\right] \mathrm{Cl},\left[\mathrm{C}_{4} \mathrm{mim}\right] \mathrm{Cl}$ and $\left[\mathrm{C}_{2} \mathrm{mim}\right] \mathrm{Cl}$. Although differences are observed with the IL cation, especially with the alkyl side chain length, the addition of functional groups does not have a particular effect on the partitioning of vanillin. Indeed, only for $\left[\mathrm{C}_{7} \mathrm{H}_{7} \mathrm{mim}\right] \mathrm{Cl}$ the partition coefficient increases slightly compared to $\left[\mathrm{C}_{7} \mathrm{mim}\right] \mathrm{Cl}$, although they are not statistically different taking into account the associated standard deviations. The results indicate that an increase in the IL cation hydrophilic character by the inclusion of additional functional groups does not improves the vanillin extraction. It seems thus that the cation-anion interaction strengths are the major forces driving the partitioning of vanillin. Weaker coulombic forces allow an easily access of vanillin to interact both with the IL cation and anion.

Regarding the IL anions effect on the vanillin extraction, shown in Fig. 4, the following rank was observed: $\left[\mathrm{C}_{4} \mathrm{mim}\right] \mathrm{Cl}>\left[\mathrm{C}_{4} \mathrm{mim}\right]\left[\mathrm{N}(\mathrm{CN})_{2}\right]>\left[\mathrm{C}_{4} \mathrm{mim}\right] \mathrm{Br}>\left[\mathrm{C}_{4} \mathrm{mim}\right]\left[\mathrm{CH}_{3} \mathrm{SO}_{4}\right]>$ $\left[\mathrm{C}_{4} \mathrm{mim}\right]\left[\mathrm{CF}_{3} \mathrm{SO}_{3}\right]>\left[\mathrm{C}_{4} \mathrm{mim}\right]\left[\mathrm{CH}_{3} \mathrm{SO}_{3}\right] \approx\left[\mathrm{C}_{4} \mathrm{mim}\right]\left[\mathrm{CH}_{3} \mathrm{CO}_{2}\right]$. Vanillin partitions preferentially for IL-rich phases composed by halogenated ions, such as $\mathrm{Cl}^{-}$or $\mathrm{Br}^{-}$, or for ILs comprising anions with a more hydrophobic character and a higher hydrogen bonding accepting character, such as $\left[\mathrm{N}(\mathrm{CN})_{2}\right]^{-}$. In addition, the fluorination of $\left[\mathrm{C}_{4} \mathrm{mim}\right]\left[\mathrm{CH}_{3} \mathrm{SO}_{3}\right]$ to a more hydrophobic IL, $\left[\mathrm{C}_{4} \mathrm{mim}\right]\left[\mathrm{CF}_{3} \mathrm{SO}_{3}\right]$, enhances the partition coefficient. Finally, the sulfate anion is more effective in extracting vanillin than the sulfonate and acetate anions. Indeed, methanesulfonate and acetate anions are strongly salting-out inducing ions, resulting therefore in lower partition coefficients, as observed before [6]. In general it is observed that vanillin extraction becomes more efficient using IL anions with a salting-in inducing behavior. Ions that usually promote the solutes salting-in increase their partition coefficients in contrast to the salting-out inducing ions that tend to decrease them. Salting-out inducing ions (high charge density ions) have a greater tendency to form hydration complexes, and thus do not interact with vanillin, decreasing therefore the respective partition coefficients. On the other hand, for salting-in inducing ions (low charge density ions) the tendency to form hydration complexes is marginal and thus they tend to stabilize the solutes in solution by specific ion binding to the solute $[16,19]$.

\subsection{Effect of temperature in vanillin partitioning}

The effect of temperature on the partition coefficients of vanillin was studied with four ILs: $\left[\mathrm{C}_{4} \mathrm{mim}\right] \mathrm{Cl},\left[\mathrm{C}_{4} \mathrm{mim}\right]\left[\mathrm{CH}_{3} \mathrm{SO}_{4}\right]$, $\left[\mathrm{C}_{7} \mathrm{H}_{7} \mathrm{mim}\right] \mathrm{Cl}$ and $[\mathrm{amim}] \mathrm{Cl}$. These ILs allowed to study whether the anion and cation suffer different influences on the temperature variations. The temperatures evaluated were $288.15 \mathrm{~K}, 298.15 \mathrm{~K}$, $308.15 \mathrm{~K}, 318.15 \mathrm{~K}$ and $328.15 \mathrm{~K}$. Accordingly to previous studies [20,23,35-36], using IL-based ATPS, the temperature was shown to be either a negligible or a significant factor in the extraction of various types of biomolecules. While He et al. [20] indicated that temperature had not significant influence on the distribution behavior of steroids, Pei et al. [23], on the other hand, reported that temperature greatly influences the extraction efficiency of proteins. As a result it can be established that the partition coefficients dependence on temperature will largely depend on the solute and ternary system under study.

The results obtained for the temperature influence on the vanillin partitioning are depicted in Fig. 5 . The results indicate that the temperature greatly influences the vanillin partition. This effect is less pronounced for systems containing the IL $\left[\mathrm{C}_{4} \mathrm{mim}\right]\left[\mathrm{CH}_{3} \mathrm{SO}_{4}\right]$. The $\left[\mathrm{C}_{4} \mathrm{mim}\right]\left[\mathrm{CH}_{3} \mathrm{SO}_{4}\right],\left[\mathrm{C}_{7} \mathrm{H}_{7} \mathrm{mim}\right] \mathrm{Cl}$ and $[\mathrm{amim}] \mathrm{Cl}$ systems have an optimum temperature for the extraction of vanillin at $298.15 \mathrm{~K}$ while for $\left[\mathrm{C}_{4} \mathrm{mim}\right] \mathrm{Cl}$ the largest partition coefficient was observed at $308.15 \mathrm{~K}$.

Both IL cation and anion contribute for the differences observed in the partition coefficients and their dependence on temperature. The presence of maximum values in the partition coefficients as a 


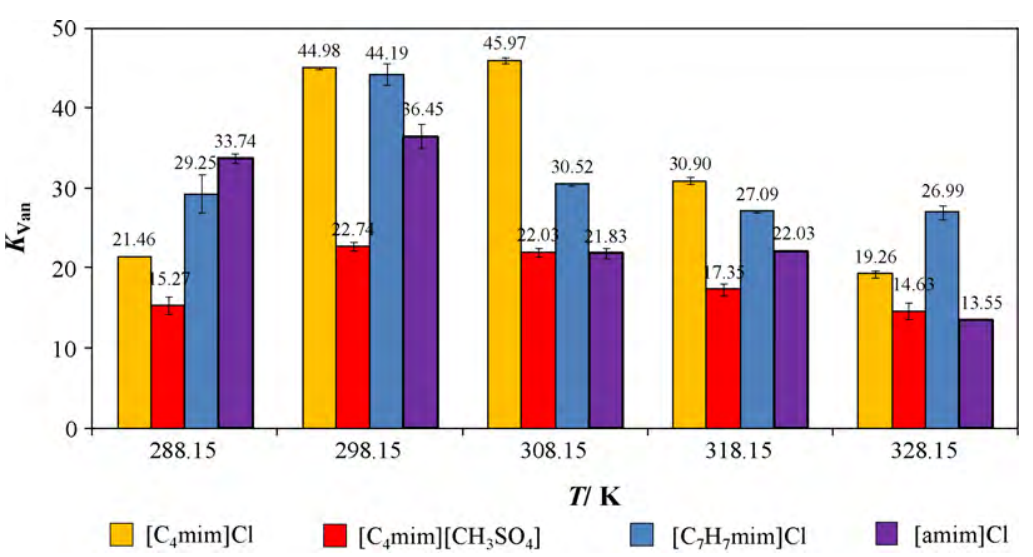

Fig. 5. Partition coefficients of vanillin in $\mathrm{IL}+\mathrm{K}_{3} \mathrm{PO}_{4}$ ATPS as a function of temperature for the ILs: $\left[\mathrm{C}_{4} \mathrm{mim}\right] \mathrm{Cl},\left[\mathrm{C}_{4} \mathrm{mim}\right]\left[\mathrm{CH} \mathrm{CO}_{4}\right],\left[\mathrm{C}_{7} \mathrm{H}_{7} \mathrm{mim}\right] \mathrm{Cl}$ and $[\mathrm{amim}] \mathrm{Cl}$.

function of temperature suggest that the partitioning of vanillin is driven by opposite effects that result from the temperature dependency of the energetic and entropic contributions.

For the systems studied, the partition coefficients of vanillin are higher than those observed for the octanol-water system [3] that also show a decrease in the partition coefficients of vanillin with the temperature increase (in the range between $298.15 \mathrm{~K}$ and $318.15 \mathrm{~K}$ ).

In order to calculate the vanillin thermodynamic parameters of transfer, such as the standard molar Gibbs energy $\left(\Delta_{\mathrm{tr}} G_{\mathrm{m}}^{0}\right)$, the standard molar enthalpy $\left(\Delta_{\mathrm{tr}} H_{\mathrm{m}}^{0}\right)$, and the standard molar entropy of transfer $\left(\Delta_{\mathrm{tr}} S_{\mathrm{m}}^{0}\right)$, the van't Hoff approach was used. The plots of $\ln \left(K_{\mathrm{Van}}\right)$ versus $1 / T$ for the four ILs studied, in the temperature range from $298.15 \mathrm{~K}$ to $328.15 \mathrm{~K}$, are provided in Supporting Information. These parameters reveal the association equilibrium between the vanillin composition in two different fluids. The following isochors were used to determine the molar thermodynamic functions of transfer (Eqs. (2)-(4)) [37-38],

$\ln \left(K_{\mathrm{Van}}\right)=-\frac{\Delta_{\mathrm{tr}} H_{\mathrm{m}}^{0}}{R} \times \frac{1}{T}+\frac{\Delta_{\mathrm{tr}} S_{\mathrm{m}}^{0}}{R}$

$\Delta_{\mathrm{tr}} G_{\mathrm{m}}^{0}=\Delta_{\mathrm{tr}} H_{\mathrm{m}}^{0}-T \Delta_{\mathrm{tr}} S_{\mathrm{m}}^{0}$

$\Delta_{\mathrm{tr}} G_{\mathrm{m}}^{0}=-R T \ln \left(K_{\mathrm{Van}}\right)$

where $K_{\mathrm{Van}}$ is the partition coefficient of vanillin, $R$ is the universal gas constant (8.314 $\left.\mathrm{J} \mathrm{mol}^{-1} \mathrm{~K}^{-1}\right), T$ is the temperature (K), and $\Delta_{\mathrm{tr}} H_{\mathrm{m}}^{0}, \Delta_{\mathrm{tr}} S_{\mathrm{m}}^{0}$ and $\Delta_{\mathrm{tr}} G_{\mathrm{m}}^{0}$ are the standard molar enthalpy of transfer, the standard molar entropy of transfer and the standard molar Gibbs energy of vanillin transfer, respectively.

For the four systems, the plots of $\ln \left(K_{\mathrm{Van}}\right)$ versus $1 / T$ exhibit linearity indicating that the molar enthalpy of transfer of vanillin is temperature independent in the temperature range between $298.15 \mathrm{~K}$ and $328.15 \mathrm{~K}$. In Table 1 , the obtained values of $\Delta_{\mathrm{tr}} G_{\mathrm{m}}^{0}$, $\Delta_{\mathrm{tr}} H_{\mathrm{m}}^{0}$ and $\Delta_{\mathrm{tr}} S_{\mathrm{m}}^{0}$ at $298.15 \mathrm{~K}$ are summarized. The calculated $\Delta_{\mathrm{tr}} G_{\mathrm{m}}^{0}$ values are negative for all the systems evaluated reflecting the spontaneous and preferential partitioning of vanillin for the IL-rich phase and as indicated by the $K_{\mathrm{Van}}>1 . \Delta_{\mathrm{tr}} H_{\mathrm{m}}^{0}$ values are negative indicating that the transference of vanillin from the $\mathrm{K}_{3} \mathrm{PO}_{4}$-rich phase to the IL-rich phase is an exothermic process which further reflects the favorable vanillin-IL type interactions.
The standard molar enthalpies of transfer largely depend on the IL anion while the effect of changing the IL cation is only relevant for cases where the chain side cation is highly complex, as for $\left[\mathrm{C}_{7} \mathrm{H}_{7} \mathrm{mim}\right] \mathrm{Cl}$. These results again suggest that the partitioning process is essentially controlled by the anion interactions with the solute.

The results here obtained show that the effect of temperature on the extraction of vanillin is highly significant and that it is necessary to control the temperature at which the extraction is performed to achieve the maximum efficiency.

\subsection{Effect of concentration in vanillin partitioning}

Fig. 6 shows the partition coefficients for different initial concentrations of vanillin. The ILs used to study this effect were $\left[\mathrm{C}_{4} \mathrm{mim}\right] \mathrm{Cl}$, $\left[\mathrm{C}_{4} \mathrm{mim}\right]\left[\mathrm{CH}_{3} \mathrm{SO}_{4}\right]$ and $\left[\mathrm{C}_{7} \mathrm{H}_{7} \mathrm{mim}\right] \mathrm{Cl}$. The range of vanillin concentrations in the water mass fraction at the ternary system varied between $0.5 \mathrm{~g} \mathrm{dm}^{-3}\left(3.3 \times 10^{-3} \mathrm{~mol} \mathrm{dm}^{-3}\right)$ and $7.5 \mathrm{~g} \mathrm{dm}^{-3}$ $\left(4.9 \times 10^{-2} \mathrm{~mol} \mathrm{dm}^{-3}\right)$. It should be pointed out that the saturation of vanillin in water at $298.15 \mathrm{~K}$ is around $10.0 \mathrm{~g} \mathrm{dm}^{-3}$ $\left(6.5 \times 10^{-2} \mathrm{~mol} \mathrm{~kg}^{-1}\right)$ [39]. For the three ILs studied there is an increase in the vanillin partition coefficients with the initial concentration of the solute. Note that the value at $7.5 \mathrm{~g} \mathrm{dm}^{-3}$ is not shown for $\left[\mathrm{C}_{4} \mathrm{mim}\right]\left[\mathrm{CH}_{3} \mathrm{SO}_{4}\right]$ since a precipitation of vanillin/ionic liquid mixture was observed at these conditions (as confirmed by NMR spectroscopic analysis). The precipitation of vanillin was found to be of $82 \mathrm{wt} \%$ and results from the salting-out inducing ability of $\left[\mathrm{C}_{4} \mathrm{mim}\right]\left[\mathrm{CH}_{3} \mathrm{SO}_{4}\right]$ as discussed before. The dependence on the initial concentration is less pronounced for the IL $\left[\mathrm{C}_{4} \mathrm{mim}\right]\left[\mathrm{CH}_{3} \mathrm{SO}_{4}\right]$, while highly noticeable with $\left[\mathrm{C}_{4} \mathrm{mim}\right] \mathrm{Cl}$ and $\left[\mathrm{C}_{7} \mathrm{H}_{7} \mathrm{mim}\right] \mathrm{Cl}$. These results suggest that the IL cation starts to largely influence the dependency of the partitioning of vanillin with the solute content. Since anions are typically more polarizable than cations, due to their more diffuse valence electronic configuration, their hydration is usually stronger than that of cations and, as a result, their saltingout effects are more prominent $[16,19]$. Thus, due to the stronger ability of anions for salting-out, and particularly of the methylsulfate anion, the presence of additional vanillin does not conduct to favorable interactions between IL anions and the solute. In

Table 1

Standard molar thermodynamic functions of transfer of vanillin at $298.15 \mathrm{~K}$.

\begin{tabular}{llll}
\hline System & $\Delta_{\mathrm{tr}} H_{\mathrm{m}}^{0}\left(\mathrm{~kJ} \mathrm{~mol}{ }^{-1}\right)$ & $\Delta_{\mathrm{tr}} S_{\mathrm{m}}^{0}\left(\mathrm{~J} \mathrm{~mol} \mathrm{~m}^{-1} \mathrm{~K}^{-1}\right)$ & $\Delta_{\mathrm{tr}} G_{\mathrm{m}}^{0}\left(\mathrm{~kJ} \mathrm{~mol} \mathrm{mon}^{-1}\right)$ \\
\hline$\left[\mathrm{C}_{4} \mathrm{mim}\right] \mathrm{Cl}+\mathrm{K}_{3} \mathrm{PO}_{4}+$ water & -24 & -47 & -10 \\
{$\left[\mathrm{C}_{4} \mathrm{mim}\right]\left[\mathrm{CH}_{3} \mathrm{SO}_{4}\right]+\mathrm{K}_{3} \mathrm{PO}_{4}+$ water } & -13 & -16 & 3.95 \\
{$\left[\mathrm{C}_{7} \mathrm{H}_{7} \mathrm{mim}\right] \mathrm{Cl}+\mathrm{K}_{3} \mathrm{PO}_{4}+$ water } & -14 & -13 & -8 \\
{$[\mathrm{amim}] \mathrm{Cl}+\mathrm{K}_{3} \mathrm{PO}_{4}+$ water } & -24 & -51 & -9 \\
\hline
\end{tabular}




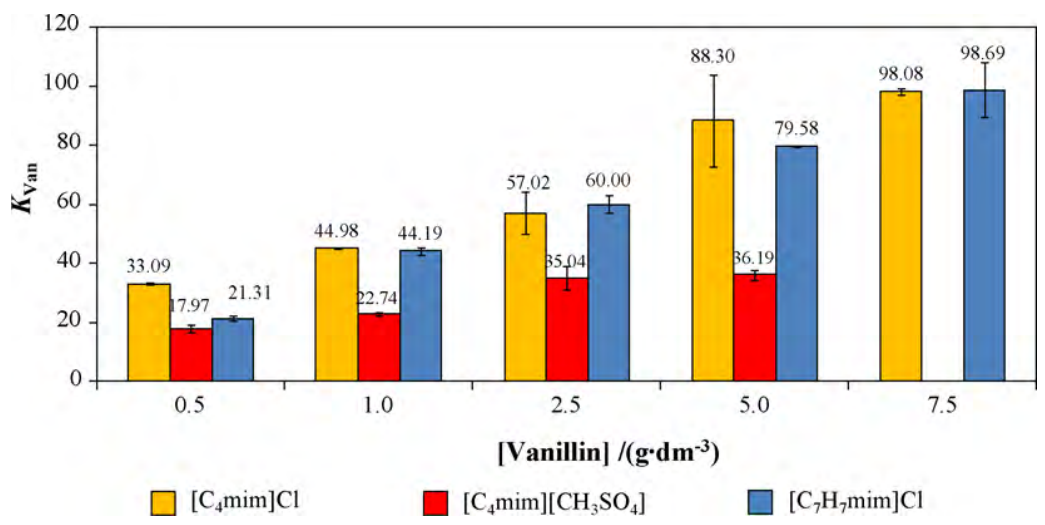

Fig. 6. Partition coefficients of vanillin in IL $+\mathrm{K}_{3} \mathrm{PO}_{4}$ ATPS as a function of initial vanillin concentration for the ILs: $\left[\mathrm{C}_{4} \mathrm{mim}\right] \mathrm{Cl}$, $\left[\mathrm{C}_{4} \mathrm{mim}\right]\left[\mathrm{CH} \mathrm{SO}_{4}\right]$ and $\left[\mathrm{C}_{7} \mathrm{H}_{7}\right.$ mim $] \mathrm{Cl}$.
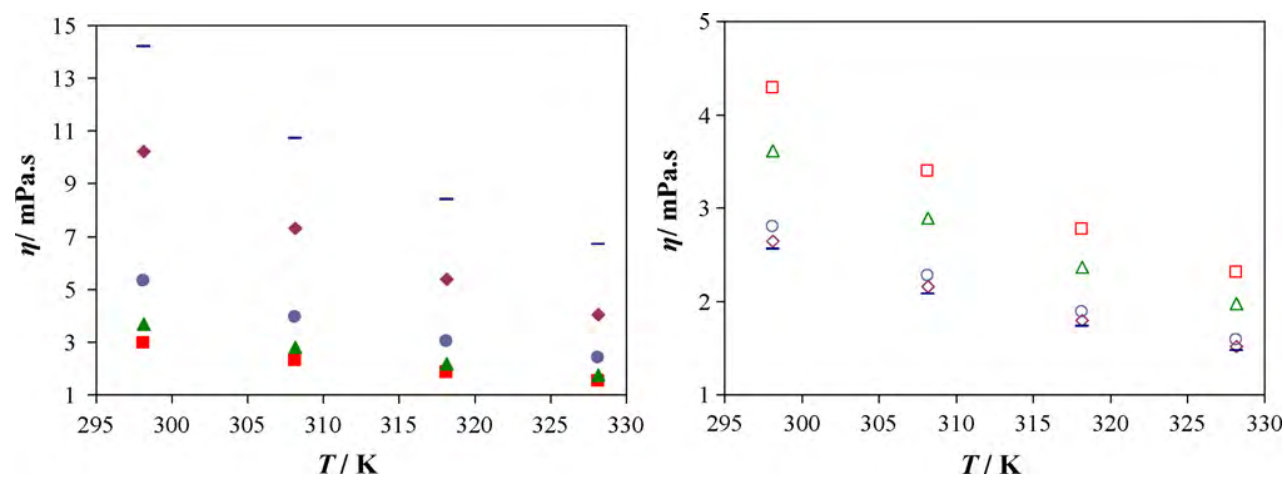

Fig. 7. Experimental viscosity $(\eta)$ as a function of temperature for the IL-rich phase (full symbols) and $\mathrm{K}_{3} \mathrm{PO}_{4}$-rich phase (open symbols) for systems composed by ILs: ( $\left[\mathrm{C}_{2} \mathrm{mim}\right] \mathrm{Cl} ;(\Delta)\left[\mathrm{C}_{4} \mathrm{mim}\right] \mathrm{Cl} ;(\bullet)\left[\mathrm{C}_{6} \mathrm{mim}\right] \mathrm{Cl} ;(\diamond)\left[\mathrm{C}_{7} \mathrm{mim}\right] \mathrm{Cl} ;(-)\left[\mathrm{C}_{10} \mathrm{mim}\right] \mathrm{Cl}$.

contrast, methylsulfate preferentially forms hydration complexes. Therefore, when increasing the vanillin content, the increase in the partition coefficients is more evident when changing the IL cation due to their higher aptitude for specific binding with the phenolic aldehyde (typical salting-in inducing ions).

\subsection{Density and viscosity}

The physical properties of the upper and lower phase in different ternary systems at various compositions and temperatures are imperative for the design and scale up of extraction processes. Therefore, densities and viscosities of all systems evaluated in this work, in the temperature range between $298.15 \mathrm{~K}$ and $328.15 \mathrm{~K}$, were determined at the following ternary composition: $15 \mathrm{wt} \%$ of $\mathrm{K}_{3} \mathrm{PO}_{4}+25 \mathrm{wt} \%$ of IL $+60 \mathrm{wt} \%$ of water (except for $\left[\mathrm{OHC}_{2} \mathrm{mim}\right] \mathrm{Cl}$ that was at $15 \mathrm{wt} \%$ of $\mathrm{K}_{3} \mathrm{PO}_{4}+40 \mathrm{wt} \%$ of IL $+45 \mathrm{wt} \%$ of water). Results are displayed in Figs. 7-14. The experimental data obtained are reported in Supporting Information. In Figs. 7 and 8, data for viscosities of the chloride-based ILs are presented. For the IL-rich phase the viscosities monotonically increase with the alkyl side chain length increase from $\left[\mathrm{C}_{2} \mathrm{mim}\right] \mathrm{Cl}(\eta=2.98 \mathrm{mPa}$ s at $298.15 \mathrm{~K})$ to $\left[\mathrm{C}_{10} \mathrm{mim}\right] \mathrm{Cl}(\eta=14.19 \mathrm{mPa} s$ at $298.15 \mathrm{~K})$. Concerning the influence of the functional groups inclusion, the viscosities of the IL-rich phase decrease in the order: $\left[\mathrm{OHC}_{2} \mathrm{mim}\right] \mathrm{Cl}(\eta=6.27 \mathrm{mPa}$ s at $298.15 \mathrm{~K})>\left[\mathrm{C}_{7} \mathrm{H}_{7} \mathrm{mim}\right] \mathrm{Cl}>\left[\mathrm{C}_{4} \mathrm{mim}\right] \mathrm{Cl}>[\mathrm{amim}] \mathrm{Cl}(\eta=2.96 \mathrm{mPa}$ at $298.15 \mathrm{~K})$. Although $\left[\mathrm{OHC}_{2}\right.$ mim] Cl presents relatively high viscosity values it should be remarked that this system is richer in IL than the remaining systems so that a direct comparison is not indeed fair. Regarding the inorganic salt-rich phase for the systems with the chloride-based ILs the values of viscosities at $298.15 \mathrm{~K}$ range between $9.25 \mathrm{mPas}$ for $\left[\mathrm{OHC}_{2} \mathrm{mim}\right] \mathrm{Cl}$ and $2.56 \mathrm{mPas}$ for $\left[\mathrm{C}_{10} \mathrm{mim}\right] \mathrm{Cl}$. An opposite trend with the ILs was observed for the
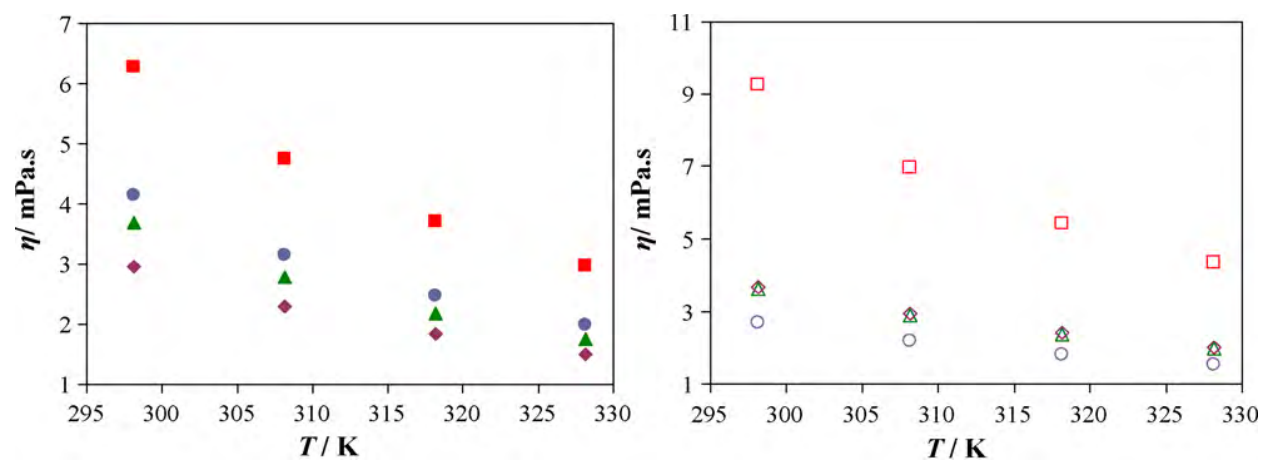

Fig. 8. Experimental viscosity $(\eta)$ as a function of temperature for the IL-rich phase (full symbols) and $\mathrm{K}_{3} \mathrm{PO}_{4}$-rich phase (open symbols) for systems composed by ILs: ( $\mathbf{\Lambda}$ ) $\left[\mathrm{C}_{4} \mathrm{mim}\right] \mathrm{Cl} ;(\bullet)[\operatorname{amim}] \mathrm{Cl} ;(\bullet)\left[\mathrm{C}_{7} \mathrm{H}_{7} \mathrm{mim}\right] \mathrm{Cl} ;(\bullet)\left[\mathrm{OHC}_{2} \mathrm{mim}\right] \mathrm{Cl}$. 

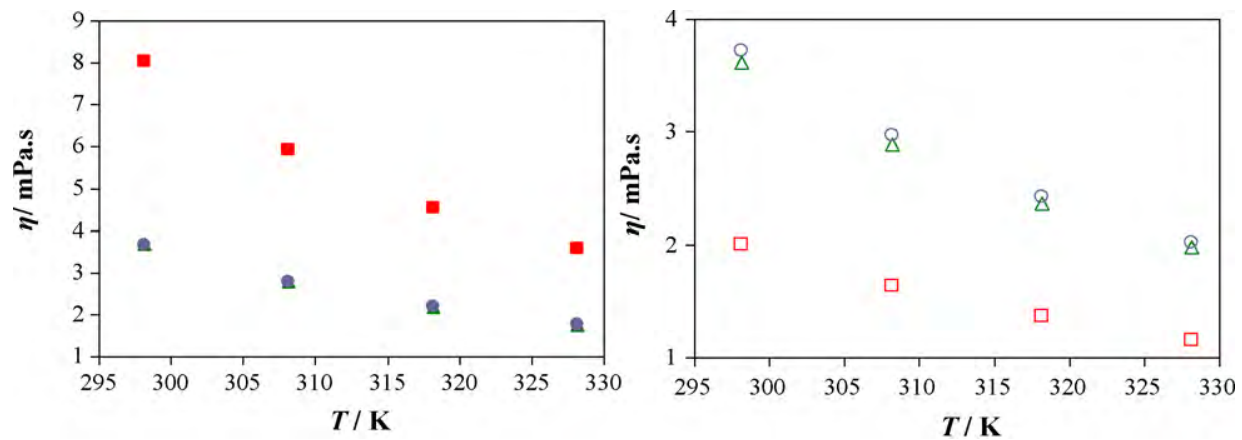

Fig. 9. Experimental viscosity $(\eta)$ as a function of temperature for the IL-rich phase (full symbols) and $\mathrm{K}_{3} \mathrm{PO}_{4}$-rich phase (open symbols) for systems composed by ILs: ( $\mathbf{\Lambda}$ ) $\left[\mathrm{C}_{4} \mathrm{mim}\right] \mathrm{Cl} ;(\bullet)\left[\mathrm{C}_{4} \mathrm{mim}\right]\left[\mathrm{CH}_{3} \mathrm{SO}_{3}\right] ;(\mathbf{\square})\left[\mathrm{C}_{4} \mathrm{mim}\right]\left[\mathrm{CF}_{3} \mathrm{SO}_{3}\right]$.
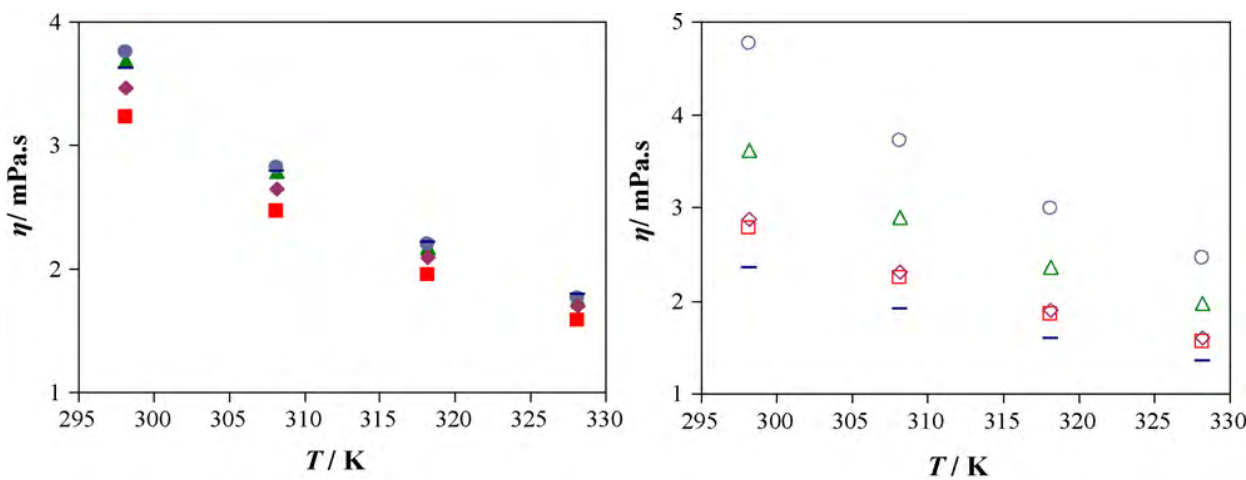

Fig. 10. Experimental viscosity $(\eta)$ as a function of temperature for the IL-rich phase (full symbols) and $\mathrm{K}_{3} \mathrm{PO}_{4}$-rich phase (open symbols) for systems composed by ILs: ( $\mathbf{\Lambda}$ ) $\left[\mathrm{C}_{4} \mathrm{mim}\right] \mathrm{Cl} ;(\bullet)\left[\mathrm{C}_{4} \mathrm{mim}\right]\left[\mathrm{CH}_{3} \mathrm{CO}_{2}\right] ;(-)\left[\mathrm{C}_{4} \mathrm{mim}\right]\left[\mathrm{N}(\mathrm{CN})_{2}\right] ;(\bullet)\left[\mathrm{C}_{4} \mathrm{mim}\right]\left[\mathrm{CH}_{3} \mathrm{SO}_{4}\right] ;(\mathbf{\square})\left[\mathrm{C}_{4} \mathrm{mim}\right] \mathrm{Br}$.
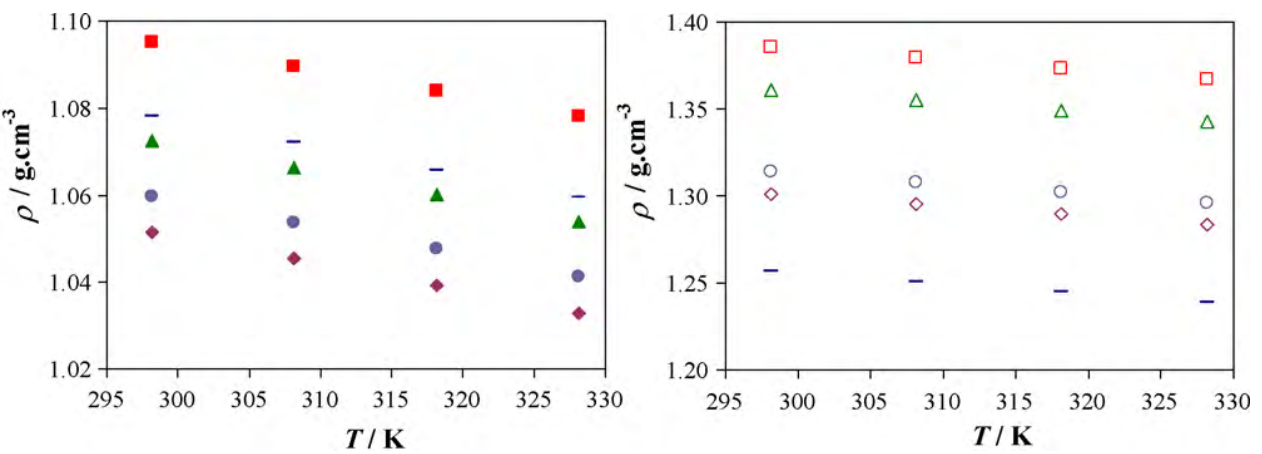

Fig. 11. Experimental density $(\rho)$ as a function of temperature for the IL-rich phase (full symbols) and $\mathrm{K}_{3} \mathrm{PO}_{4}$-rich phase (open symbols) for systems composed by ILs: ( $\left[\mathrm{C}_{2} \mathrm{mim}\right] \mathrm{Cl} ;(\boldsymbol{\Delta})\left[\mathrm{C}_{4} \mathrm{mim}\right] \mathrm{Cl} ;(\bullet)\left[\mathrm{C}_{6} \mathrm{mim}\right] \mathrm{Cl} ;(\bullet)\left[\mathrm{C}_{7} \mathrm{mim}\right] \mathrm{Cl} ;(-)\left[\mathrm{C}_{10} \mathrm{mim}\right] \mathrm{Cl}$.
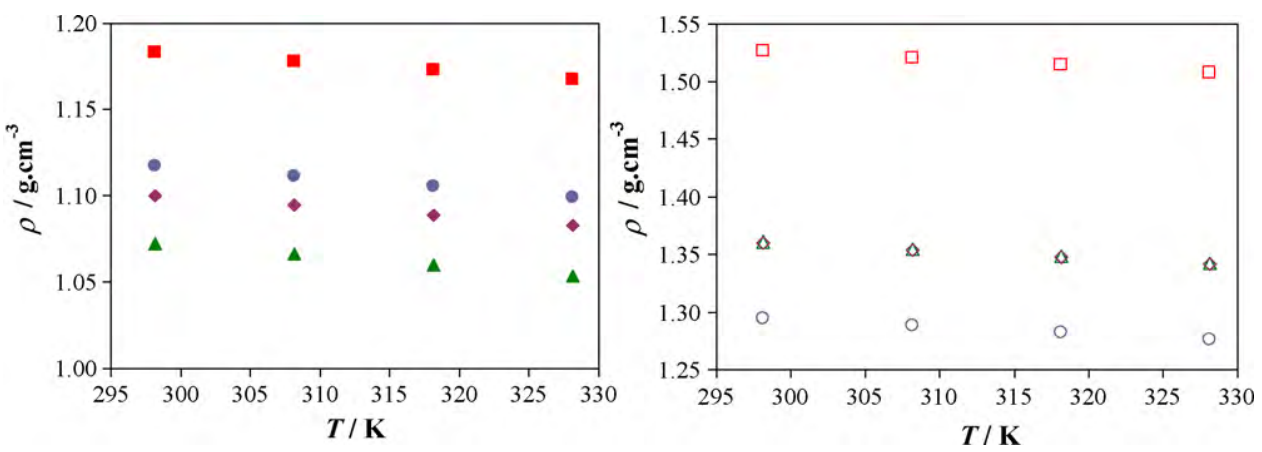

Fig. 12. Experimental density $(\rho)$ as a function of temperature for the IL-rich phase (full symbols) and $\mathrm{K}_{3} \mathrm{PO}_{4}$-rich phase (open symbols) for systems composed by ILs: ( $\mathbf{\Lambda}$ ) $\left[\mathrm{C}_{4} \mathrm{mim}\right] \mathrm{Cl} ;(\bullet)[\mathrm{amim}] \mathrm{Cl} ;(\bullet)\left[\mathrm{C}_{7} \mathrm{H}_{7} \mathrm{mim}\right] \mathrm{Cl} ;(\boldsymbol{\square})\left[\mathrm{OHC}_{2} \mathrm{mim}\right] \mathrm{Cl}$. 

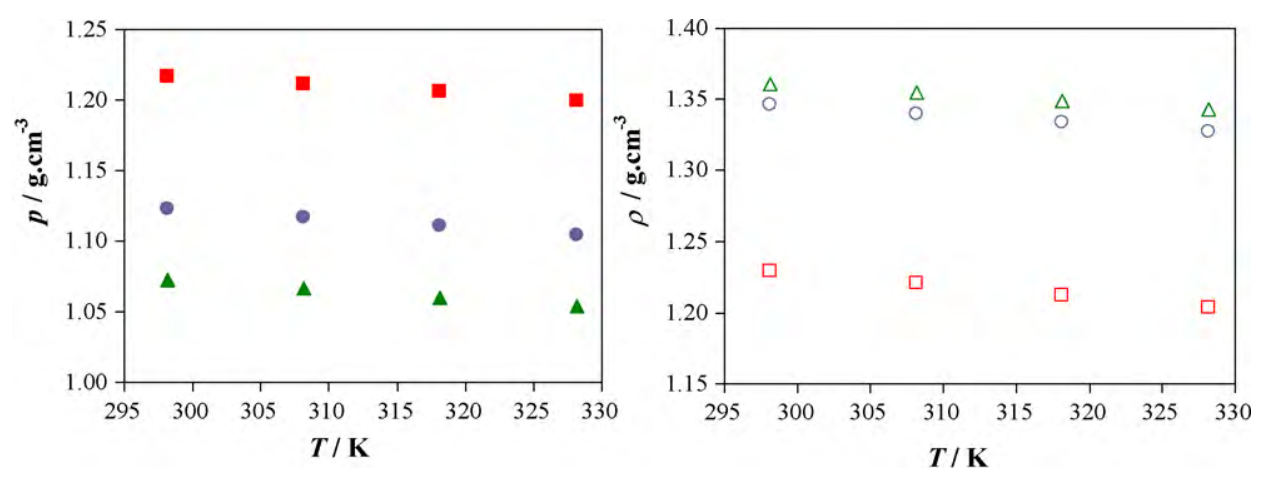

Fig. 13. Experimental density $(\rho)$ as a function of temperature for the IL-rich phase (full symbols) and $\mathrm{K}_{3} \mathrm{PO}_{4}$-rich phase (open symbols) for systems composed by ILs: ( $\mathbf{\Lambda}$ ) $\left[\mathrm{C}_{4} \mathrm{mim}\right] \mathrm{Cl} ;(\bullet)\left[\mathrm{C}_{4} \mathrm{mim}\right]\left[\mathrm{CH}_{3} \mathrm{SO}_{3}\right] ;(\mathbf{\square})\left[\mathrm{C}_{4} \mathrm{mim}\right]\left[\mathrm{CF}_{3} \mathrm{SO}_{3}\right]$.
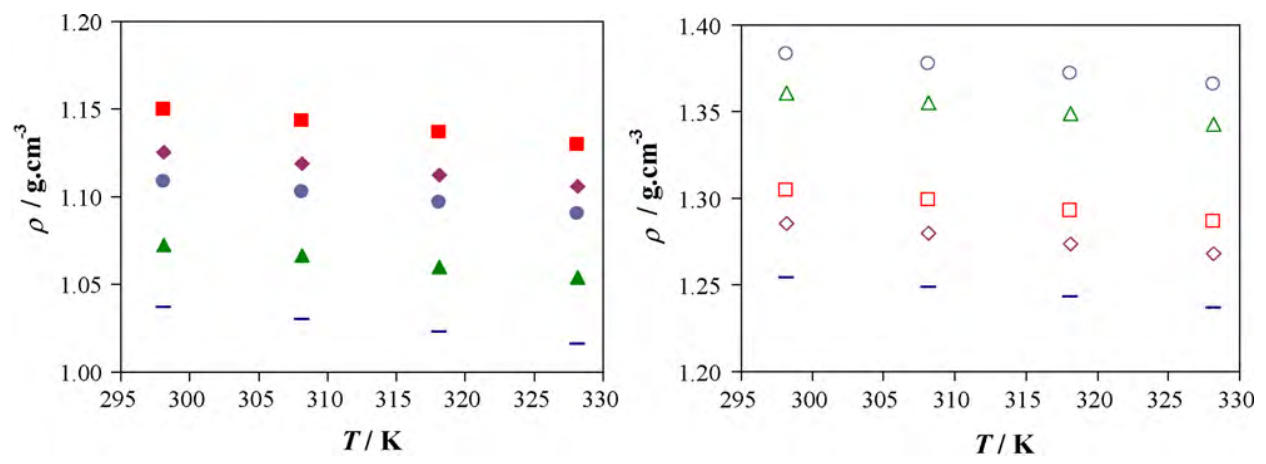

Fig. 14. Experimental density $(\rho)$ as a function of temperature for the IL-rich phase (full symbols) and $\mathrm{K}_{3} \mathrm{PO}_{4}$-rich phase (open symbols) for systems composed by ILs: ( $\mathbf{\Lambda}$ ) $\left[\mathrm{C}_{4} \mathrm{mim}\right] \mathrm{Cl} ;(\bullet)\left[\mathrm{C}_{4} \mathrm{mim}\right]\left[\mathrm{CH}_{3} \mathrm{CO}_{2}\right] ;(-)\left[\mathrm{C}_{4} \mathrm{mim}\right]\left[\mathrm{N}(\mathrm{CN})_{2}\right] ;(\diamond)\left[\mathrm{C}_{4} \mathrm{mim}\right]\left[\mathrm{CH}_{3} \mathrm{SO}_{4}\right] ;(\mathbf{\square})\left[\mathrm{C}_{4} \mathrm{mim}\right] \mathrm{Br}$.

viscosities at the $\mathrm{K}_{3} \mathrm{PO}_{4}$-rich phase. The opposite trends are in good agreement with each other since the most viscous ILs are also the least water soluble.

The viscosities of the IL-rich phases are surprisingly low for ATPS and also sometimes lower than the viscosities observed at the $\mathrm{K}_{3} \mathrm{PO}_{4}$-rich phase. This trend was observed for systems composed by $\left[\mathrm{C}_{2} \mathrm{mim}\right] \mathrm{Cl},\left[\mathrm{C}_{4} \mathrm{mim}\right] \mathrm{Cl},\left[\mathrm{OHC}_{2} \mathrm{mim}\right] \mathrm{Cl}$ and $[\mathrm{amim}] \mathrm{Cl}$. In particular for $\left[\mathrm{C}_{4} \mathrm{mim}\right] \mathrm{Cl}$ there is an inversion on the relative viscosities with the temperature.

The viscosity data for $\left[\mathrm{C}_{4} \mathrm{mim}\right]$-based ILs are depicted in Figs. 9 and 10. The results for the IL-rich phase shows that the $\left[\mathrm{C}_{4} \mathrm{mim}\right]\left[\mathrm{CF}_{3} \mathrm{SO}_{3}\right]$ system $(\eta=8.05 \mathrm{mPas}$ at $298.15 \mathrm{~K})$ presents the higher viscosity while $\left[\mathrm{C}_{4} \mathrm{mim}\right][\mathrm{Br}] \quad(\eta=3.23 \mathrm{mPas}$ at $298.15 \mathrm{~K}$ ) presents the lower viscosity values. The viscosity data at $298.15 \mathrm{~K}$, and at the same mass fraction compositions, decrease in the following order: $\left[\mathrm{C}_{4} \mathrm{mim}\right]\left[\mathrm{CF}_{3} \mathrm{SO}_{3}\right]>\left[\mathrm{C}_{4} \mathrm{mim}\right]$ $\left[\mathrm{CH}_{3} \mathrm{CO}_{2}\right]>\left[\mathrm{C}_{4} \mathrm{mim}\right] \mathrm{Cl}>\left[\mathrm{C}_{4} \mathrm{mim}\right]\left[\mathrm{CH}_{3} \mathrm{SO}_{3}\right]>\left[\mathrm{C}_{4} \mathrm{mim}\right]\left[\mathrm{N}(\mathrm{CN})_{2}\right]>$ $\left[\mathrm{C}_{4} \mathrm{mim}\right]\left[\mathrm{CH}_{3} \mathrm{SO}_{4}\right]>\left[\mathrm{C}_{4} \mathrm{mim}\right] \mathrm{Br}$. The viscosities of the salt-rich phase at $298.15 \mathrm{~K}$ range between $4.76 \mathrm{mPa}$ s for $\left[\mathrm{C}_{4} \mathrm{mim}\right]\left[\mathrm{CH}_{3} \mathrm{CO}_{2}\right]$ and $2.00 \mathrm{mPa}$ s for $\left[\mathrm{C}_{4} \mathrm{mim}\right]\left[\mathrm{CF}_{3} \mathrm{SO}_{3}\right]$. Again, and as observed with the chloride-based ILs, the viscosity of the inorganic salt-rich phase is higher for the systems containing the ILs $\left[\mathrm{C}_{4} \mathrm{mim}\right]\left[\mathrm{CH}_{3} \mathrm{SO}_{3}\right]$ and $\left[\mathrm{C}_{4} \mathrm{mim}\right]\left[\mathrm{CH}_{3} \mathrm{CO}_{2}\right]$.

One of the critical problems related to the polymer-based ATPS is the high viscosity of the polymer-rich phases [40,41]. It was previously shown [13] that phosphonium-based ATPS displayed lower viscosities than polymer-based ATPS. As shown here the imidazolium-based ATPS present even lower viscosity values than their phosphonium counterparts which is highly beneficial in industrial processes. The low viscosity systems favors the mass transfer of the solute between the two phases, as well as in improving the phases handling.

The density data for all the studied systems are presented in Figs. $11-14$, in the temperature range between $298.15 \mathrm{~K}$ and
$328.15 \mathrm{~K}$. In all equilibrated systems the density of the $\mathrm{K}_{3} \mathrm{PO}_{4}-$ rich phase is higher than the density of the IL-rich phase. Only for the system containing $\left[\mathrm{C}_{4} \mathrm{mim}\right]\left[\mathrm{CF}_{3} \mathrm{SO}_{3}\right]$ the densities of both phases are very similar. For the IL-rich phase the value of densities at $298.15 \mathrm{~K}$ range between $1.0366 \mathrm{~g} \mathrm{~cm}^{-3}$ for $\left[\mathrm{C}_{4} \mathrm{mim}\right]\left[\mathrm{N}(\mathrm{CN})_{2}\right]$ and $1.2169 \mathrm{~g} \mathrm{~cm}^{-3}$ for $\left[\mathrm{C}_{4} \mathrm{mim}\right]\left[\mathrm{CF}_{3} \mathrm{SO}_{3}\right]$. For the bottom phase $\left(\mathrm{K}_{3} \mathrm{PO}_{4}\right.$-rich phase $)$ the density values at $298.15 \mathrm{~K}$ range between $1.2291 \mathrm{~g} \mathrm{~cm}^{-3}$ in the system with $\left[\mathrm{C}_{4} \mathrm{mim}\right]\left[\mathrm{CF}_{3} \mathrm{SO}_{3}\right]$ and $1.5265 \mathrm{~g} \mathrm{~cm}^{-3}$ for the system composed by $\left[\mathrm{OHC}_{2} \mathrm{mim}\right] \mathrm{Cl}$. Comparing IL-based ATPS and typical polymer-inorganic salt ATPS [40] there are not significant differences in the density values. In both systems the top phase is the IL- or polymer-rich phase, while the bottom layer is the inorganic salt-rich phase.

\section{Conclusions}

In this work the optimization of the IL structure for the improved extraction of vanillin was experimentally determined by measuring the partition coefficients on several IL-based ATPS. The effect of the IL cation and anion structure, the temperature of equilibrium and the concentration of the solute were evaluated. All the studied parameters have shown to influence the extraction of vanillin. For all the studied systems, and at all the conditions analyzed, vanillin preferentially partitions for the IL-rich phase presenting $K_{\mathrm{Van}}>1$. The partition coefficients dependency with the cation alkyl chain length displays a maximum for the system formed by $\left[\mathrm{C}_{6} \mathrm{mim}\right] \mathrm{Cl}$ resulting from a decrease in the polar character of the IL cation and lower surface tension at the IL-rich phase. The introduction of features such as double bounds, benzyl and hydroxyl groups had only a marginal impact on the partition coefficients of vanillin. Regarding the IL anion, vanillin partitions preferentially for ILs composed by halogenated anions, such as $\mathrm{Cl}^{-}$or $\mathrm{Br}^{-}$, or by anions with a higher hydrogen bonding accepting character, such as $\left[\mathrm{N}(\mathrm{CN})_{2}\right]^{-}$. The influence 
of temperature in the partitioning of vanillin presented a maximum in the extraction efficiency at $298.15 \mathrm{~K}$ for $\left[\mathrm{C}_{4} \mathrm{mim}\right]\left[\mathrm{CH}_{3} \mathrm{SO}_{4}\right]$, $\left[\mathrm{C}_{7} \mathrm{H}_{7} \mathrm{mim}\right] \mathrm{Cl}$ and $[\mathrm{amim}] \mathrm{Cl}$ and at $308.15 \mathrm{~K}$ for $\left[\mathrm{C}_{4} \mathrm{mim}\right] \mathrm{Cl}$. Moreover, the partition coefficients of vanillin increased monotonically with the initial concentration of the solute added to the global system. Variations in the partition coefficients as a function of the vanillin concentration were more dependent on the IL cation nature.

The viscosities of the IL-rich phase in all IL-based ATPS studied were found to be substantially lower than those observed in typical polymer-based ATPS bringing improved advantages for industrial applications of the systems here studied.

\section{Acknowledgments}

This work had a financial support from "BIIPP: Biorefinaria Integrada na Indústria de Pasta Para Papel” (QREN 11551). Mara G. Freire acknowledges Fundação para a Ciência e a Tecnologia for the post-doctoral grant SFRH/BPD/41781/2007.

\section{Appendix A. Supplementary data}

Supplementary data associated with this article can be found, in the online version, at doi:10.1016/j.seppur.2010.07.007.

\section{References}

[1] L.J. Esposito, K. Formanek, G. Kientz, F. Mauger, V. Maureaux, G. Robert, F Truchet, Vanillin, Kirk-Othmer Encyclopedia of Chemical Techology, John Wiley \& Sons, New York, 1997.

[2] M.B. Hocking, J. Chem. Educ. 74 (1997) 1055.

[3] A. Noubigh, A. Mgaidi, M. Abderrabba, J. Chem. Eng. Data 55 (2010) 488

[4] A.J. Daugulis, D.B. Axford, B. Ciszek, J. Malinowski, J. Biotechnol. Lett. 16 (1994) 637.

[5] M. Martínez-Aragón, S. Burghoff, E.L.V. Goetheer, A.B. de Haan, Sep. Purif. Technol. 65 (2009) 65.

[6] S.P.M. Ventura, C.M.S.S. Neves, M.G. Freire, I.M. Marrucho, J. Oliveira, J.A.P. Coutinho, J. Phys. Chem. B 113 (2009) 9304.

[7] J. Rydberg, C. Musikas, G.R. Choppin, Principles and Practices of Solvent Extraction, Marcel Dekker, Inc, New York, 1992.

[8] P.A. Albertsson, Nature 182 (1958) 709.

[9] L.I.N. Tomé, V.R. Catambas, R.R. Teles, M.G. Freire, I.M. Marrucho, J.A.P. Coutinho, Sep. Purif. Technol. 72 (2010) 167.
[10] C.M.S.S. Neves, S.P.M. Ventura, M.G. Freire, I.M. Marrucho, J.A.P. Coutinho, J. Phys. Chem. B 113 (2009) 5194.

[11] M. Domínguez-Pérez, L.I.N. Tomé, M.G. Freire, I.M. Marrucho, O. Cabeza, J.A.P. Coutinho, Sep. Purif. Technol. 72 (2010) 85.

[12] K.E. Gutowski, G.A. Broker, H.D. Willauer, J.G. Huddleston, R.P. Swatloski, J.D. Holbrey, R.D. Rogers, J. Am. Chem. Soc. 125 (2003) 6632.

[13] C.L.S. Louros, A.F.M. Cláudio, C.M.S.S. Neves, M.G. Freire, I.M. Marrucho, J. Pauly, J.A.P. Coutinho, Int. J. Mol. Sci. 11 (2010) 1777.

[14] M.G. Freire, P.J. Carvalho, R.L. Gardas, I.M. Marrucho, L.M.N.B.F. Santos, J.A.P. Coutinho, J. Phys. Chem. B 112 (2008) 1604.

[15] M.G. Freire, C.M.S.S. Neves, P.J. Carvalho, R.L. Gardas, A.M. Fernandes, I.M. Marrucho, L.M.N.B.F. Santos, J.A.P. Coutinho, J. Phys. Chem. B 111 (2007) 13082.

[16] M.G. Freire, P.J. Carvalho, A.M.S. Silva, L.M.N.B.F. Santos, L.P.N. Rebelo, I.M. Marrucho, J.A.P. Coutinho, J. Phys. Chem. B 113 (2009) 202.

[17] L.I.N. Tomé, F.R. Varanda, M.G. Freire, I.M. Marrucho, J.A.P. Coutinho, J. Phys. Chem. B 113 (2009) 2815.

[18] L.I.N. Tomé, M. Domínguez-Pérez, A.F.M. Cláudio, M.G. Freire, I.M. Marrucho, O. Cabeza, J.A.P. Coutinho, J. Phys. Chem. B 113 (2009) 13971.

[19] M.G. Freire, C.M.S.S. Neves, A.M.S. Silva, L.M.N.B.F. Santos, I.M. Marrucho, L.P.N Rebelo, J.K. Shah, E.J. Maginn, J.A.P. Coutinho, J. Phys. Chem. B 114 (2010) 2004.

[20] C. He, S. Li, H. Liu, K. Li, F. Liu, J. Chromatogr. A 1082 (2005) 143.

[21] S. Li, C. He, H. Liu, K. Li, F. Liu, J. Chromatogr. B 826 (2005) 58.

[22] A. Soto, A. Arce, M.K. Khoshkbarchi, Sep. Purif. Technol. 44 (2005) 242.

[23] Y.C. Pei, J.J. Wang, K. Wu, X.P. Xuan, X.J. Lu, Sep. Purif. Technol. 64 (2009) 288.

[24] Q.F. Liu, J. Yu, W.L. Li, X.S. Hu, H.S. Xia, H.Z. Liu, P. Yang, Sep. Sci. Technol. 41 (2006) 2849.

[25] M.J. Earle, J.M.S.S. Esperança, M.A. Gilea, J.N.C. Lopes, L.P.N. Rebelo, J.W. Magee, K.R. Seddon, J.A. Widegren, Nature 439 (2006) 831.

[26] T. Welton, Chem. Rev. 99 (1999) 2071.

[27] S. Park, R. Kazlauskas, J. Curr. Opin. Biotechnol. 14 (2003) 432.

[28] F. van Rantwijk, R.A. Sheldon, Chem. Rev. 107 (2007) 2757

[29] S. Dreyer, U. Kragl, Biotechnol. Bioeng. 99 (2008) 1416.

[30] P. Wasserscheid, W. Keim, Angew. Chem. Int. Ed. 39 (2000) 3773.

[31] P.A. Albertsson, Partitioning of Cell Particles and Macromolecules, Wiley, New York, 1986.

[32] P.J. Flory, Principles of Polymer Chemistry, Cornell University Press, Ithaca, New York, 1953.

[33] P.J. Carvalho, M.G. Freire, I.M. Marrucho, A.J. Queimada, J.A.P. Coutinho, J. Chem Eng. Data 53 (2008) 1346.

[34] J.N. Canongia Lopes, A.A.H. Pádua, J. Phys. Chem. B 110 (2006) 3330

[35] J. Wang, Y. Pei, Y. Zhao, Z. Hu, Green Chem. 7 (2005) 196.

[36] Z. Du, Y.L. Yu, J.H. Wang, Chem. Eur. J. 13 (2007) 2130.

[37] V.M. Boddu, K. Abburi, S.W. Maloney, R. Damavarapu, Hazard. Mater. 155(2008) 288.

[38] C. Ottiger, H. Wunderli-Allenspach, Pharm. Res. 16 (1999) 643.

[39] A. Noubigh, A. Mgaidi, M. Abderrabba, E. Provost, W. Furst, J. Sci. Food Agric. 87 (2007) 783.

[40] L.H. Mei, D.Q. Lin, Z.Q. Zhu, Z.X. Han, J. Chem. Eng. Data 40 (1995) 1168.

[41] M. Perumalsamy, T. Murugesan, J. Chem. Eng. Data 54 (2009) 1359. 